\title{
Anastrepha spp. (Diptera: Tephritidae) in Ximenia Americana and Other Tropical Fruits in a Brazilian Savannah
}

\author{
Almerinda Amélia Rodrigues Araújo \\ State Department of Education and Culture of Piauí (SEDUC), Teresina, PI, Brazil
}

(86) 3216-3394 E-mail: almerindaaraujor@gmail.com

José Ribamar Gusmão Araújo

State University of Maranhão (UEMA), São Luís, MA, Brazil

(98) 2016-8150, Ramal 5046, E-mail: gusmaoaraujo50@gmail.com

Raimunda Nonata Santos Lemos (Corresponding author)

State University of Maranhão (UEMA), São Luís, MA, Brazil

(98) 2016-8150, Ramal 5046, E-mail: rlemos@cca.uema.br

Paulo Roberto Ramalho Silva

Federal University of Piauí (UFPI), Teresina, PI, Brazil

(86) 3215-5747 E-mail: pauloramalho@ufpi.edu.br

Solange Maria França

Federal University of Piauí (UFPI), Teresina, PI, Brazil

(86) 3215-5747 E-mail: amanteigados@yahoo.com.br

Lízio Laguna Soares

Federal University of Piauí (UFPI), Teresina, PI, Brazil

(86) 3215-5747 E-mail: 1soares18@hotmail.com 
Anne Caroline Bezerra dos Santos

State University of Maranhão (UEMA), São Luís, MA, Brazil

(98) 2016-8150, Ramal 5046, E-mail: annecaroline.bsantos@gmail.com

Mário Luiz Ribeiro Mesquita

State University of Maranhão (UEMA), São Luís, MA, Brazil

(98) 2016-8150, Ramal 5046, E-mail: mario-mesquita51@ @otmail.com

Received: December 1, 2020

Accepted: February 1, 2021 Published: February 7, 2021

doi:10.5296/jas.v9i1.18009

URL: https://doi.org/10.5296/jas.v9i1.18009

\begin{abstract}
The aim of this work was to evaluate the infestation of Anastrepha species in several fruit tree species and A. alveata in wild plum Ximenia americana L. (Olacaceae), as well as the fruit fly community in a Savannah area using faunal indexes and population fluctuation. For this, we installed McPhail traps and carried out collections at Palmeiras home garden, municipality of São Pedro of Piauí, state of Piaui, northeastern Brazil. We noted high infestation of A. alveata in wild plum, with 144.2 puparia $/ \mathrm{kg}, 216.1$ puparia $/ \mathrm{kg}$ and 321.6 puparia/kg for the years 2014, 2015 and 2016 respectively. The infestation indexes of $A$. obliqua in red mombin (Spondias purpurea) were 146.1 puparia/kg in 2016 and 479.2 puparia/kg in 2017, and in umbu-hog plum (Spondias bahiensis) 607.3 puparia/kg in 2017, both from the Anacardiaceae family. The species that composed the fruit fly community were A. alveata, A. ethalea (predominant), A. obliqua, A. zenildae (dominant and accessory), A. sororcula and $A$. fraterculus (accidental). The population fluctuation of $A$. ethalea occurred from March to October, while A. alveata presented population peaks in the fruiting of wild plum, between October and December.
\end{abstract}

Keywords: Anastrepha alveata, Anastrepha ethalea, infestation index, faunistic analysis, Population fluctuation

\title{
1. Introduction
}

Brazil, the current third largest fruit producer in the world after China and India, has a highly diversified fruit production sector that occupies approximately two million hectares. However, Brazil is ranked $23^{\text {rd }}$ among fruit-exporting countries in South America. This is because phytosanitary embargoes at destination locations limit Brazil's access to the foreign market. This mainly occurs, particularly when the pest of interest is of quarantine relevance at destination markets, for instance of several species of Tephritidae (PNDF/MAPA, 2020). 
Fruit flies are insects that cause considerable damage to fruits. Fruit flies represent one of the main obstacles to international fresh-fruit trade in Brazil. The process of oviposition by the females flies and the opening of galleries inside the fruit by larvae, characteristic damages caused by fruit flies, make them unfit for human consumption.

Approximately 70 species of these tephritids contribute to the phytosanitary problems in the fruit sector; the genera Anastrepha Schiner, Bactrocera Macquart, Ceratitis MacLeay and Dacus Fabricus contribute to the majority of these problems (Garcia et al., 2017). Within the genus Anastrepha, the species A. fraterculus and A. obliqua that mainly infest plants of the Anacardiaceae and Myrtaceae families, are species of economic interest throughout Brazil (Leite et al., 2017).

Although the species A. alveata Stone is not considered a pest, it is uncommon and so far has only been reported in one host in Mexico, the wild plum Ximenia americana L. (Olacaceae) (Piedra et al., 1993; Aluja et al., 2014). Because this species is little-known, in Brazil, it has only been documented from traps in population surveys and recently its biological and behavioral aspects have been studied in conjunction with X. americana (Araújo et al., 2019).

The wild plum is a cosmopolitan botanical species that is usually found in Africa, India, New Zealand, Central and South America. In Brazil, it is found mainly in the semi-arid region and coastal plains of the Northeast; widely distributed in several forest ecosystems (Sarmento et al., 2015).

The fruits are round (both length and diameter $=2 \mathrm{~cm}$ ), and yellow-skinned when ripe, with a single cream-colored almond seed (Almeida el al., 2016). The pulp that has a firm consistency, is aromatic and has a sweet and sour flavor. The short fruiting is concentrated between October and December, in the first rains.

In all areas of where the plum is found (based on folk medicine), research has been done on the wild plum to identify new drugs or substances that can serve as a model for the synthesis of new drugs due to its therapeutic properties (Sobeh et al., 2017).

The most studied fruit fly species in tropical and subtropical regions are those of economic interest, especially those with a varied number of hosts (polyphagous or oligophagous). However, focus should also be directed to monophagous species rely ona single host as a food resource. For instancet, A. alveata is only found in X. americana (Araújo et al., 2014).

Research on trophic interactions between fruit flies and their hosts is vital to support the development of appropriate management techniques for polyphagous or oligophagous species and to maintain monophagous species in their natural environments (Uchôa, 2012).

The objective of this study conducted in the Brazilian savannah, was to study the infestation and population fluctuation of Anastrepha species in different fruits and of A. alveata in wild plum, as well as to describe the composition of the fruit fly community by means of fauna analysis.

\section{Materials and Methods}




\subsection{Study area: Location and Characteristics}

The research was carried out at Palmeiras home garden ( $05^{\circ} 53^{\prime} 15,3^{\prime \prime} \mathrm{S}$ and $\left.42^{\circ} 43^{\prime} 28,3^{\prime \prime} \mathrm{W}\right)$, municipality of São Pedro do Piauí, state of Piauí, northeastern Brazil, $106 \mathrm{~km}$ from state capital Teresina $\left(05^{\circ} 55^{\prime} 46\right.$ "S and 42 $\left.43^{\prime} 07^{\prime \prime} \mathrm{W}\right)$, with altitude of $264 \mathrm{~m}$ (CEPRO, 2011). The climate in the region is of the as type, according to Köppen classification, that is, tropical hot, with a rainy season from January to June and a dry season from July to December. The average rainfall is $1,200 \mathrm{~mm}$ and the average temperature is $26^{\circ} \mathrm{C}$ (Aguiar, 2004).

The research was carried out in a demarcated area of 4 ha of typical cerradão vegetation (Brazilian savannah) with areas of babassou forest, (Orbygnia phalerata Mart.) Arecaceae, representing the characteristics of a secondary-type vegetation.

\subsection{Survey of Anastrepha spp. in Traps and Directly in Fruits}

We installed 13 McPhail traps in randomly distributed wild plum plants at height of 3/4 of each the plant's height. The plants geographical position were recorded by GPS (Global Position System) Garmin CHX Legender ${ }^{\circledR}$, where 05 53'15.3"S and 42 $43^{\prime} 28.3^{\prime \prime} \mathrm{W}$ was the georeferenced starting point (Figure 1). We supplied the traps with attractive feed based on hydrolyzed maize protein (Bio Anastrepha $\left.{ }^{\circledR}\right)$, diluted to $5 \%(400 \mathrm{~mL}$ of attractant). We replaced the attractive feed fortnightly.

Samples of ripe wild plum fruits were collected weekly (freshly fallen fruits or on the plant). While fruits of other botanical species were collected fortnightly throughout each year according to the fruiting season, including red mombin Spondias purpurea L., umbu-hog plum Spondias bahiensis P. Carvalho, Van den Berg \& M. Machado (Machado et al., 2015) mango Mangifera indica L., bush-passion-fruit Passiflora laurifolia L., brave-cotton Cochlospermum vitifolium (Willd.) Spreng, coroata Bromelia pinguin L., marmelo-do-cerrado Alibertia edulis (L. Rich) A. Riche, pau-terra Quelea parviflora Mart., guabiraba Campomanesia xantrocarpa Berg, lobeira Solanum lycocarpum St. Hil., araticum-do-cerrado Annona crassiflora Mart, mandacaru Cereus jamacaru DC., maniçoba Manihot pseudoglaziovii Pax \& Hoffman. The sample size varied according to fruit availability.

We placed the fruits in trays and the trap content in plastic bottles and transported them to the Entomology Laboratory, Agricultural Sciences Center (CCA) of the Federal University of Piauí (UFPI), in Teresina. We performed the steps of separating fruits and sorting the content of the traps in the Laboratory.

Samples of wild plum fruits and other botanical species, collected from November / 2014 to September / 2017, were counted, grouped by species (biomass defined in $\mathrm{kg}$ ) and packed in plastic trays (dimensions $40 \times 25 \times 7 \mathrm{~cm}$ ) containing autoclaved sand as a substrate for pupation.

The puparia were extracted by sieving, counted and kept in plastic containers $(250 \mathrm{~mL})$ with moist sand, covered with voile fabric and kept in the breeding room under controlled climatic conditions (temperature $27 \pm 2{ }^{\circ} \mathrm{C}$, air RH of $70 \pm 5 \%$ ) until emergence of adults. In 2015 and 


\section{Macrothink Institute $^{\mathrm{TM}}$}

2016, 40 wild plum fruits were sampled per collection (four in total). The fruits were individually weighed and placed in plastic containers $(50 \mathrm{~mL})$ with autoclaved and moist sand, wrapped in voile and kept in the breeding room under the same climatic conditions and above mentioned procedures.

Emerged adult fruit flies were inactivated in a freezer (10 min permanence), then fixed in $70 \%$ ethanol as well as the specimens collected in traps. Specimens were sexed and identified based on female characteristics, since the vast majority of Anastrepha species are female.

\subsection{Infestation Index of Anastrepha spp. in Sampling with Grouped Fruits}

We computed the above Index with the formula:

$\mathrm{I}=$ number of pupils obtained / $\mathrm{kg}$ of fruits and number of pupils / fruits.

2.4 Infestation Index and Infestation Intensity of A. alveata on Individualized Wild Plum Fruits

It was computed based on Corsato (2004): where

fly infestation index $(\%)=($ infested fruits/total fruits $) \times 100$;

infestation intensity (I.I.) $=($ number of puparia/mass $)$,

where mass is the total weight of infested fruits $(\mathrm{kg})$.

\subsection{Pest Species Identification}

We identified the species based on identification keys provided by Zucchi (2000) and Zucchi et al. (2011). The identified specimens were stored in $70 \%$ ethanol and deposited at the Entomology Laboratory of UFPI (campus of Teresina) and at the Iraci Paiva Coelho Entomological Collection (CIPC) in the Maranhão State University, in São Luís, state of Maranhão.

\subsection{Botanical Species}

Information on fruiting season and fruit collection of botanical species were based on in loco observations throughout each year.

\subsection{Faunistic Analysis}

We carried out the Anastrepha species diversity analysis based on Silveira Neto et al. (1976). The estimated parameters were frequency, dominance, constancy, Shannon Diversity Index and Equitability. The ANAFAU software (Moraes et al., 2003) was used for computations.

\subsection{Population Fluctuation}

The population fluctuation analysis was based on the total number of Anastrepha adults caught in the traps. The population seasonal variations were based on the monthly catch of the number of specimens per species (females) and of adults (females and males) (from November/2014 to December/2017). Population fluctuation was analyzed in relation to climatic variables of total rainfall $(\mathrm{mm})$, average temperature $\left({ }^{\circ} \mathrm{C}\right)$ and average relative 


\section{Macrothink}

Journal of Agricultural Studies

ISSN 2166-0379 2021, Vol. 9, No. 1

humidity (\%). Meteorological data were obtained from the National Institute of Meteorology (INMET), from the Ministry of Agriculture, Livestock and Supply, through the Automatic Stations.

\subsection{Statistical Analyses}

The correlation of climatic variables on the number of adults and Anastrepha species was assessed by computing the Pearson correlation coefficient (SAS Institute, 2001).

\section{Results and Discussion}

We documented 3,215 Anastrepha specimens, 669 in traps and 2,546 in fruits. Seven species were captured from the traps (Table 1) and two from the fruits (Table 2).

Table 1. Species and number of Anastrepha adults collected through McPhail traps installed in Ximenia americana plants at Palmeiras home garden, municipality of São Pedro of Piauí, northeastern Brazil (from Nov./2014 to Dec./2017)

\begin{tabular}{|c|c|c|c|}
\hline \multirow{2}{*}{ Years } & \multicolumn{3}{|c|}{ Anastrepha spp. } \\
\hline & Females & Males & Total \\
\hline 2014 & $\begin{array}{l}14 \\
09 \text { A. alveata } \\
03 \text { A. obliqua } \\
02 \text { A. fraterculus }\end{array}$ & 3 & 17 \\
\hline 2015 & $\begin{array}{l}81 \\
65 \text { A. alveata } \\
11 \text { A. ethalea } \\
04 \text { A. obliqua } \\
01 \text { A. zenildae }\end{array}$ & 49 & 130 \\
\hline 2016 & $\begin{array}{l}104 \\
62 \text { A. alveata } \\
29 \text { A. ethalea } \\
09 \text { A. obliqua } \\
02 \text { A. sororcula } \\
02 \text { A. zenildae }\end{array}$ & 60 & 164 \\
\hline 2017 & $\begin{array}{l}169 \\
64 \text { A. alveata } \\
86 \text { A. ethalea } \\
14 \text { A. obliqua } \\
03 \text { A. zenildae } \\
02 \text { Anastrepha sp. }\end{array}$ & 189 & 358 \\
\hline $\begin{array}{c}\text { Total } \\
\text { percentage }\end{array}$ & $\begin{array}{l}368 \\
55 \%\end{array}$ & $\begin{array}{l}301 \\
45 \%\end{array}$ & $\begin{array}{l}669 \\
100 \%\end{array}$ \\
\hline
\end{tabular}


Table 2. Infestation rates of Anastrepha spp. obtained in Ximenia americana fruits, Spondias purpurea and Spondias bahiensis, collected at Palmeiras home garden, municipality of São Pedro of Piauí, northeastern Brazil (from Nov./2014 to Dec./2017)

\begin{tabular}{|c|c|c|c|c|c|c|c|}
\hline \multirow[t]{2}{*}{ Years } & \multicolumn{2}{|c|}{ Fruits } & \multirow{2}{*}{$\begin{array}{c}\text { Puparia } \\
\text { N }\end{array}$} & \multirow{2}{*}{$\begin{array}{c}\text { Infestation } \\
\text { rate* }^{*} \\
\text { (fruits } / \mathrm{kg} \text { ) }\end{array}$} & \multicolumn{3}{|c|}{ Anastrepha spp. } \\
\hline & Species & $\mathrm{N} / \mathrm{kg}$ & & & q & 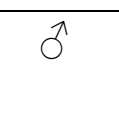 & Total \\
\hline 2014 & X. americana & $639 / 2.754$ & 397 & $0.62 / 144.2$ & $\begin{array}{c}140 \text { A. } \\
\text { alveata }\end{array}$ & 165 & 305 \\
\hline 2015 & X. americana & $897 / 3.419$ & 739 & $0.82 / 216.1$ & $\begin{array}{l}255 \text { A. } \\
\text { alveata }\end{array}$ & 265 & 520 \\
\hline \multirow[t]{2}{*}{2016} & X. americana & $1,423 / 5.293$ & 1,702 & $1.2 / 321.6$ & $385 A$. & 379 & 764 \\
\hline & S. purpurea & $83 / 0.739$ & 108 & $1.3 / 146.1$ & $\begin{array}{l}\text { alveata } \\
35 \text { A. } \\
\text { obliqua }\end{array}$ & 38 & 73 \\
\hline \multirow[t]{2}{*}{2017} & S. purpurea & $105 / 1.010$ & 484 & $4.6 / 479.2$ & $116 A$ & 119 & 235 \\
\hline & S. bahiensis & $148 / 1.062$ & 645 & $4.4 / 607.3$ & $\begin{array}{c}\text { obliqua } \\
135 \text { A. } \\
\text { obliqua }\end{array}$ & 175 & 310 \\
\hline Total & & $3,295 / 14.277$ & 4,075 & - & 1,066 & 1,141 & 2,207 \\
\hline
\end{tabular}

* $1^{\text {st }}$ value: puparia/fruit; $2^{\text {nd }}$ value: puparia/kg.

In the state of Piauí, with the exception of A. ethalea and A. zenildae, the species A. obliqua and A. fraterculus were recorded in yellow mombin (Sousa et al., 2017) and A. alveata in wild plum (Araújo et al., 2014).

Twenty-six plant species belonging to 21 botanical families were collected; only three species of two families had fruit fly infestations: red mombin $S$. purpurea, umbu-hog plum $S$. bahiensis (Anacardiaceae) and wild plum X. americana (Olacaceae).

We observed only two records associated A. alveata within the wild plum as host. Similar results were reported in Veracruz, Mexico and in the state of Piauí, northeastern Brazil (Piedra et al., 1993; Araújo et al., 2014). Injuries observed in fruits resulted in considerable infestation indexes, with 144.2 puparia/kg (0.62 puparia/fruits), 216.1 puparia/kg (0.82 puparia/fruits) and 321.6 puparia/kg (1.2 puparia/fruits) for the years 2014, 2015 and 2016 respectively (Table 2). Araújo et al. (2014) also observed high infestation index of A. alveata in wild plum (158.9 puparia/kg), in a fruit survey previously carried out in the same area.

Based onthe results obtained from this study, it could be inferred that A. alveata is strictly a monophagous wild plum pest, with no succession in other hosts, in a three-year period of wild plum tree fruiting.

No other fruit fly species collected in the area was noted infesting the wild plum. This is despite the abundance of fruits and the characteristic exhaled aroma, factors considered attractive to fruit flies of polyphagous habit. However, there are documented records of $A$. 
fraterculus associated with the wild plum (Piedra et al., 1993; Araújo et al., 2014).

Anastrepha obliqua was found infesting red mombin and umbu-hog plum with considerable infestation indexes (Table 2).

Infestation indexes in red mombin showed increasing values, with 146.1 puparia/kg (1.3 puparia/fruits) in 2016 and 479.2 puparia/kg (4.6 puparia/fruits) in 2017. In umbu-hog plum, A. obliqua infestation was observed only in 2017 , whose index of 607.3 puparia/ $\mathrm{kg}$ (4.4 puparia/fruits) was as high as in red mombin in the same year. This can be attributed to the fact that both species are primary hosts and the fruiting of the umbu-hog plum succeeds that of the fruiting of red mombin.

Anastrepha obliqua is a polyphagous species, with high rates of infestation, mainly in hosts of the genus Spondias. This was recorded in the states of Piauí in S. mombin (Araújo et al., 2014; Gomes Neto et al., 2016; Sousa et al., 2017), Bahia, in S. purpurea (Leite et al., 2017) and Amapá, in S. dulcis, S. mombin and S. purpurea (Lemos et al., 2017).

The infestation indices and infestation intensity of $A$. alveata were analyzed with data from fruit collections in 2015 and 2016. A. alveata in wild plum fruits showed a considerable infestation intensity when compared with the infestation index (Table 3).

Table 3. Infestation index (\%) and infestation intensity (II) of Anastrepha alveata in Ximenia americana fruits collected at Palmeiras home garden, municipality of São Pedro of Piauí, northeastern Brazil (from Nov./2014 to Dec./2017)

\begin{tabular}{|c|c|c|c|c|c|c|c|}
\hline \multirow[t]{2}{*}{ Years } & \multicolumn{3}{|c|}{ Fruits $(\mathrm{N})$} & \multirow[t]{2}{*}{ Puparia } & \multicolumn{2}{|c|}{ Infestation } & \multirow[t]{2}{*}{ Adults $\left(\mathrm{N}^{\circ}\right)$} \\
\hline & Collected & Infested & $\begin{array}{c}\text { Mass } \\
(\mathrm{kg})\end{array}$ & & $\%$ & I.I. & \\
\hline 2015 & 200 & 79 & 0.377 & 159 & 39.5 & 421.75 & 144 \\
\hline 2016 & 200 & 173 & 0.714 & 442 & 86.5 & 619.04 & 195 \\
\hline
\end{tabular}

According to Corsato (2004), the relationship between infestation index and infestation intensity is not always constant. This is because the percentage of infested fruits does not directly measure the infestation intensity; an infested fruit even with only one larva, is a lost fruit. Therefore, the infestation intensity does not quantify production loss.

However, with a higher the number of larvae in fruits, a larger number of the adult population that will emerge in the next generation. The infestation intensity serves as a prognosis for the infestation index of future fruiting periods, which may affect production at some level.

In this study, this is clearly observed when comparing the yearly infestation intensity of $A$. alveata in 2015 (421.75) and 2016 (619.04), which represented a 46.78\% increase from one year to the other and, consequently, an increase in the number of adults in $35.42 \%$, which could probably infest more fruits.

An intrinsic behavior of $A$. alveata, distinct from polyphagous/multivoltine species, is the gradual increase of infestation during the host fruiting, as new populations are generated. This increases the level of damage if timely control measures are not adopted. In the case of 
A. alveata, we noted an intense fruit attack at the beginning of the fruiting period, but the intensity regressed as fruits reached the end of the fruiting period, when they were free of attack.

Therefore, since A. alveata is a monophagous species of a host with annual and concentrated fruiting and it is also univoltine, as some Anastrepha species, such as A. crebra Stone and A. bezzii Lima. These species are monophagous and apparently univoltine, whose adults must survive for long periods and deal with high environmental variability, which, according to Aluja et al. (1999), determines the timing of fruit production of their host plants. This explains the initial high infestation of A. alveata in order to guarantee a new population that will wait until the next year's fruiting period.

We inspected the traps 78 times during the sampling period and 368 Anastrepha females were captured, represented by seven species (Table 4).

Table 4. Frequency, dominance and constancy of Anastrepha species caught in McPhail-type traps installed in Ximenia americana plants in a Savannah area, at Palmeiras home garden, municipality of São Pedro of Piauí, state of Piaui, northeastern Brazil (from Nov./2014 to Dec./2017)

\begin{tabular}{lccccc}
\hline Species & Cap. & $\mathrm{N}$ & Freq. (\%) & Dom.* & Cons.** \\
\hline $\begin{array}{l}\text { A. } \text { alveata } \\
\text { A. } \text { ethalea }\end{array}$ & 58 & 200 & 54.35 & $\mathrm{~d}$ & $\mathrm{w}$ \\
$\begin{array}{l}\text { A. } \text { oblique } \\
\text { A. zenildae }\end{array}$ & 18 & 126 & 34.25 & $\mathrm{~d}$ & $\mathrm{w}$ \\
$\begin{array}{l}\text { A. sororcula } \\
\text { A. fraterculus }\end{array}$ & 6 & 6 & 8.15 & $\mathrm{~d}$ & $\mathrm{y}$ \\
Anastrepha $\mathrm{sp}$. & 2 & 2 & 0.54 & $\mathrm{n}$ & $\mathrm{y}$ \\
\hline
\end{tabular}

Diversity Index (Shannon-Weaner) $=>\mathrm{H}=1.0549$

$\mathrm{IC}(\mathrm{P}=0.05)=>[1.050281 ; 1.059469]$

Uniformity Index or Equity $=>\mathrm{E}=0.5421$

$\mathrm{N}$ : total females caught; ${ }^{*} \mathrm{~d}$ : dominant, $\mathrm{n}$ : non-dominant; ${ }^{*} \mathrm{w}$ : constant, $\mathrm{y}$ : accessory

The analysis of Anastrepha catches on traps pointed to a sharp aggregate distribution of females, with four traps $(30.77 \%)$, capturing $61.41 \%$ of females. We installed the traps near 
the cultivated fruit trees, in an area more shaded by plant density, which probably influenced the increase of catches.

Four species were dominant in the fruit fly community, A. alveata, A. ethalea, A. obliqua and A. zenildae (Table 4). This implies that they are adapted to the environmental conditions of the area and therefore they may influence appearance of other tephritid species. In this case, the dominance of more than one species in the community can explain the existence of only seven species in the area. Among these species, A. alveata and A. ethalea were predominant, as they presented the highest faunal indexes in the classes of each analyzed category.

Anastrepha alveata was the most frequent of captured female, followed by A. ethalea. The highest constancy values demonstrated by the catches, were also observed for these two species, with values above $50 \%$. These were also present in the area for the longest (months) throughout the year.

The presence of $A$. alveata was conditional on the fruiting of the wild plum, occurring between September and December, while A. ethalea, with unknown host, was present in almost every month of each year, except in December. The highest constancy values were also observed for these two species, with values above $50 \%$.

Anastrepha obliqua and A. zenildae had a frequency of below $10 \%$ and the remaining had a frequency of below $1.0 \%$. Additionally, all were considered accessory as regards constancy as they appeared in those collected in short periods of the year (from one to three months) (Table 4).

The Shannon Diversity Index value of 1.05449 is a consequence of the high frequency of $A$. alveata, as evidenced by the higher number of specimens collected. However, this dominant effect was minimized by the high constancy of the presence of A. ethalea, as reflected in Equitability index of 0.5421 (Table 4). If A. ethalea was excluded from the community, the Equitability index would be lower.

In this study, A. alveata was considered predominant, revealing a new profile in relation to the records previously made in Brazil. According to Araújo et al. (2014) the number of specimens collected in surveys with traps, did not reach $1 \%$, compared to other species of Anastrepha. In Mexico, during a 12-year period, only 11 A. alveata specimens were collected in Veracruz (Ordano et al., 2013) in a fruit fly survey in Citrus maxima L. orchards.

Anastrepha ethalea, also considered predominant by faunal indexes, was not seen in association with any fruit of the sampled plant species. In Brazil, there is no host record for $A$. ethalea (Zucchi, 2008) however but it is considered a fruit pest of Passiflora species (Subhagan et al., 2020).

We noted the occurrence of some P. laurifolia plants in the area but no A. ethalea infestation was detected in the fruits collected. The records of $A$. ethalea in the state of Piauí were no more than two specimens under monitoring in commercial mango and citrus orchards (Menezes et al., 2000; Santos \& Pádua, 2004; Feitosa et al., 2008). On the other hand, in the state of Maranhão, two specimens were recorded (Holanda, 2012) and the state of Roraima, $A$. 


\section{Macrothink}

ethalea was represented by a specimen in a guava orchard (Trassato et al., 2016).

Anastrepha obliqua was also a dominant species in surveys carried out through traps in Brazil (Santos \& Pádua, 2004; Feitosa et al., 2008; Azevedo et al., 2010; Santos et al., 2011; Holanda, 2012; Marsaro Junior. et al., 2013).

Anastrepha zenildae, analyzed as a dominant species, has its largest area of occurrence in the semiarid region, as recorded in surveys conducted in the states of Ceará and Minas Gerais (Azevedo et al., 2010; Alvarenga et al., 2010). The species A. sororcula, A. fraterculus classified as non-dominant and accidental, were dominant and constant in other surveys.

A. sororcula stands out in guava orchards in the Brazilian northeastern region, (Sousa et al., 2017), and A. fraterculus in citrus orchards and temperate climate fruits in the southern and southeastern regions (Oliveira et al., 2017). Therefore, the geographic distribution of Anastrepha spp. is not uniform, but conditioned to adaptation patterns according to the abiotic conditions of each region.

We assessed the Anastrepha adult population fluctuation collected in traps in relation to climatic variables and species with the largest number of specimens in order to know the dynamics of adults in a three-year period (Figure 2. The fluctuation of adults (females and males) was continuous, except in September and October of 2015, when no specimens were captured. The highest peaks of each year occurred in December 2015, October 2016 and August and December 2017. There were two considerable peaks in 2017, one in August, caused by the most expressive increase in male population, and in December, with the increase in female population (Figure 1A). 

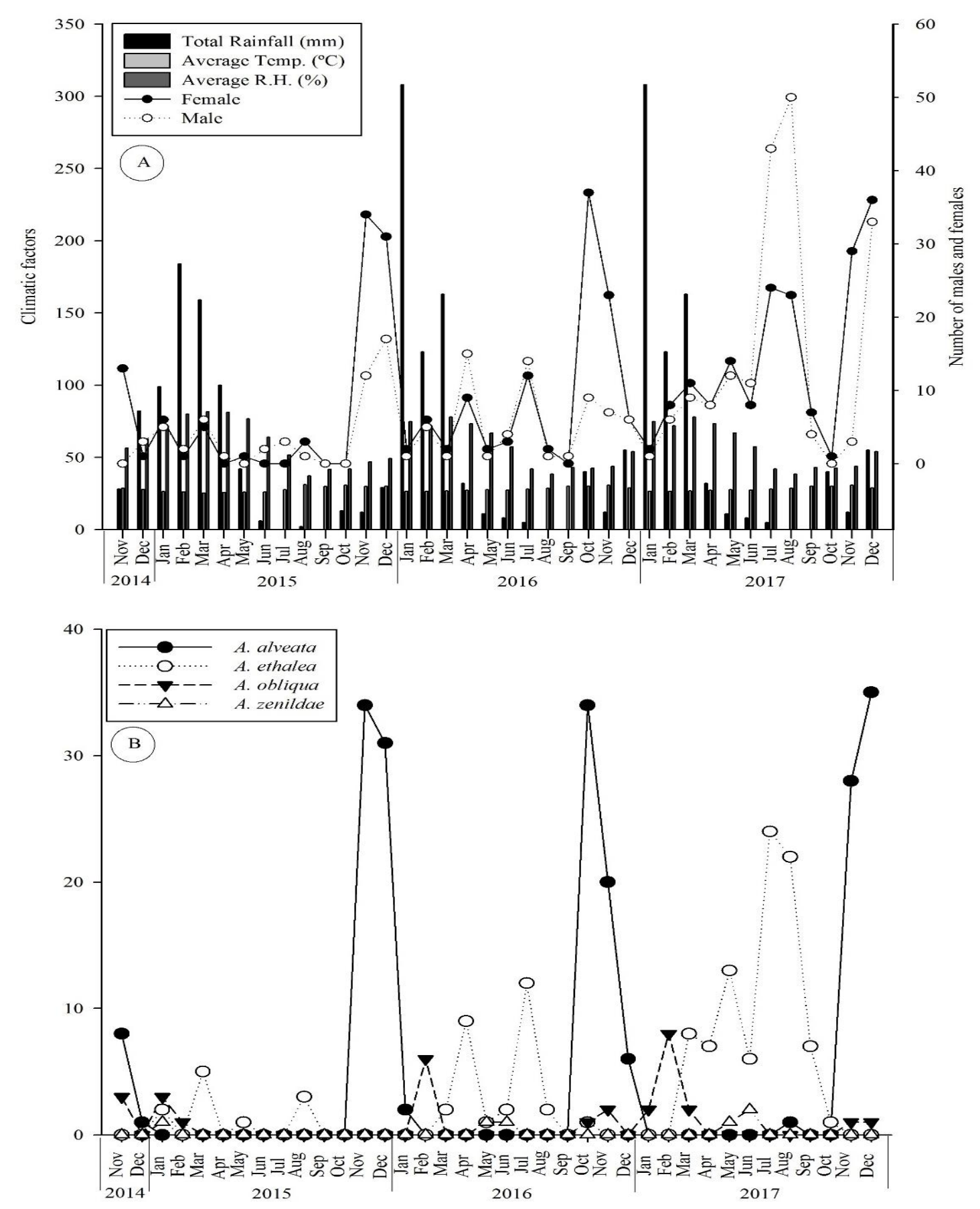

Figure 1. Population fluctuation of Anastrepha females and males under climatic conditions of total rainfall $(\mathrm{mm})$, average temperature $\left({ }^{\circ} \mathrm{C}\right)$ and average relative humidity $(\%)(\mathrm{A})$ of species A. alveata, A. ethalea, A. oblique and A. zenildae (B), collected in McPhail traps installed in Ximenia americana plants, in a Savannah area at Palmeiras home garden, municipality of São Pedro of Piauí, state of Piaui, northeastern Brazil (from Nov./2014 to

Dec./2017)

With the exception of $A$. alveata, whose capture showed a positive correlation only with temperature $(\mathrm{r}=0.66241$ and $\mathrm{P}=0.0001)$, the other captures of adults and the most frequent 
Anastrepha species did not correlate with climatic analyzed parameters (Figures 1A and 1B). For both fruit fly species, catches occurred due to the availability of fruits, wild plum for $A$. alveata, and red mombin and umbu-hog plum for A. obliqua. The same cannot be said for the other two species, A. zenildae and A. ethalea, which had no association with any collected fruit of the botanical species.

According to Santos et al. (2011), fruit availability and climatic conditions (rainfall, temperature and air humidity) are determining factors for the occurrence of fruit flies. It was observed in this study, that as regards the population dynamics of fruit flies, particularly for $A$. alveata and A. ethalea, the availability of host fruits is a crucial survival factor for A. alveata, while for A. ethalea no host was identified. However, as these two species were adapted to the Savannah environment, we assume that the climatic conditions of the area are favorable factors for the life dynamics of these species.

Anastrepha alveata showed the highest population fluctuation peaks of (Figure 1B), (Nov/2015, Oct./2016 and Dec./2017), which coincided with the wild plum fruiting, marked by great fruit availability. After fruiting in the subsequent months, A. alveata was no longer captured, revealing that its presence is synchronized with its host phenology.

The temporal distribution of A. ethalea occurred between March to October, with an almost total absence in the subsequent months, registering a population peak in July / 2017 (Figure 1B).

It was not possible to relate the population fluctuation of $A$. ethalea to fruits of any of the botanical species sampled, even those that showed occurrence of fruits in population peaks, such as brave-cotton $C$. vitifolium, coroata $B$. pinguin $\mathrm{L}$, marmelo-do-cerrado A. edulis and pau-terra $Q$. parviflora.

Anastrepha obliqua showed peaks, but not with an annual continuity, only with the Anacardiaceae family fruiting season, which, despite the existence of mangoes,was infestation observed only in Spondias species, red mombin and umbu-hog plum. The occurrence of $A$. zenildae was sporadic, probably associated with the family Myrtaceae fruits in the area, although no infestations were found.

This study was conducted in an area botanically dominated by Savannah species. We found population peaks of $A$. alveata and A. ethalea in fruit fly populations. Both species are little known, due to the scarcity of studies in native vegetation given the strong reduction of native savannah vegetation, notably in the state of Piauí. Therefore, it is necessary to urgently study such endemic species under high extinction-threat and avoid the extinction of knowledge of the ecological interactions associated with these species.

\section{Conclusions}

A. alveata is a univoltine, monophagous pest of the wild plum species due toits high infestation rate and intensity. In a savannah area in the state of Piauí, northeastern Brazil, there are seven predominant species in the fruit fly community: A. alveata, A. ethalea, A. obliqua, A. zenildae, A. sororcula, A. fraterculus and Anastrepha sp.

A. alveata has population peaks in the fruiting of wild plum and A. obliqua in the fruiting of 
red mombin Spondias purpurea and umbu-hog plum Spondias bahiensis.

The population fluctuation of A. ethalea ranges from February to November.

\section{Acknowledgements}

We thank to the State Department of Education and Culture of Piauí, SEDUC-PI, for the granting of the first author's leave for the postgraduate course (Doctorate) and the Federal University of Piauí, UFPI, for the support of this research. To FAPEMA - Foundation for Research and Scientific and Technological Development Support of Maranhão for financial support (PROCESS: CBIOMA-02946/12).

\section{References}

Aguiar, R. B., \& Gomes, J. R. C. (2004). Projeto cadastro de fontes de abastecimento por água subterrânea: estado do Piauí: diagnóstico do município de São Pedro do Piauí. Fortaleza: CPRM - Serviço Geológico do Brasil. 19p.

http://rigeo.cprm.gov.br/xmlui/bitstream/handle/doc/16504/Rel_SaoPedrodoPiaui.pdf?sequen $\mathrm{ce}=1.10$ Aug. 2020 .

Almeida, M. L. B., Souza Freitas, W. E., Morais, P. L. D., Sarmento, J. D. A., \& Alves, R. E. (2016). Bioactive compounds and antioxidant potential fruit of Ximenia americana L. Food Chemistry, 23, 1078-1082. https://doi.org/10.1016/j.foodchem.2015.07.129

Aluja, M., Piñero, J., Jácome I., Díaz-Fleischer, F., \& Sivinski J. (1999). Behavior of flies in the genus Anastrepha (Trypetinae: Toxotrypanini). In M. Aluja \& A. L. Norrbom (Org.), Fruit Flies (Diptera: Tephritidae): phylogeny and evolution of behavior (pp. 375-406). Boca Raton: CRC Press. https://doi.org/10.1590/S0301-80591999000400001

Aluja, M., Sivinski, J., Van Driesche, R., Anzures-Dadda, A., \& Guillén, L. (2014). Pest management through tropical tree conservation. Biodiversity and Conservation, 23(4), 831-853. https://doi.org/10.1007/s10531-014-0636-3

Alvarenga, C. D., Alves, D. A., Silva, M. A., Lopes, E. N., \& Lopes, G. N. (2010). Moscas-das-frutas (Diptera: Tephritidae) em pomares da área urbana no norte de Minas Gerais. Revista Caatinga, 23(2), 25-31.

https://periodicos.ufersa.edu.br/index.php/caatinga/article/view/1738/4565. 12 Aug. 2020.

Araújo, A. A. R., Lemos, R. N. S., Araujo, J. R. G., Silva, P. R. R., Franca, S. M., Corsato, C. D. A., ... Silva, L. G. (2019). Bioecology of Anastrepha alveata Stone (Diptera: Tephritidae) associated with wild plum fruits Ximenia americana L. (Olacaceae) [online]. Australian Journal of Crop Science, 13(6), 1025-1030. https://doi.org/10.21475/ajcs.19.13.06.p1959

Araújo, A. A. R., Silva, P. R. R., Querino, R. B., Silva, E. P. S., \& Soares, L. L. (2014). Moscas-das-frutas (Diptera: Tephritidae) associadas às frutíferas nativas de Spondias spp. (Anacardiaceae) e Ximenia americana L. (Olacaceae) e seus parasitoides no estado do Piauí, Brasil. Semina: Ciências Agrárias, 35(4), 1739-1750.

https://doi.org/10.5433/1679-0359.2014v35n4p1739

Azevedo, F. R., Guimarães, J. A., Simplício, A. A. F., \& Santos, H. R. (2010). Análise faunística e flutuação populacional de moscas-das-frutas (Diptera: Tephritidae) em pomares 
comerciais de goiaba na região do Cariri cearense. Arquivos do Instituto Biológico, 77(1), 33-41. https://doi.org/10.1590/1808-1657v77p0332010

CEPRO - Fundação Centro de Pesquisas Econômicas e Sociais do Piauí. (2011). http://www.cepro.pi.gov.br/download/201106/CEPRO21_54d89dde55.pdf 05 Aug. 2020.

Corsato, C. D. A. (2004). Moscas-das-frutas (Diptera: Tephritidae) em pomares de goiaba no Norte de Minas Gerais: biodiversidade, parasitóides e controle biológico (Tese Doutorado). Piracicaba: Escola Superior de Agricultura Luiz de Queiroz - Universidade de São Paulo, 83p. https://www.researchgate.net/profile/Clarice_Alvarenga/publication/34977953_Moscas-das frutas_Diptera_Tephritidae_em_pomares_de_goiaba_no_norte_de_Minas_Gerais_biodiversi dade_parasitoides_e_controle_biologico/links/0deec52d52ab483700000000/Moscas-das-frut as-Diptera-Tephritidae-em-pomares-de-goiaba-no-norte-de-Minas-Gerais-biodiversidade-par asitoides-e-controle-biologico.pdf. 28 Jul. 2020.

Feitosa, S. S., Silva, P. R. R., Pádua, L, E. M., Carvalho, E. M. S., Paz, J. K. S., \& Paiva, D. R. (2008). Flutuação populacional de moscas-das-frutas (Diptera: Tephritidae) associadas a variedades de manga no Município de José de Freitas, Piauí. Revista Brasileira de Fruticultura, 30(1), 112-117. https://doi.org/10.1590/S0100-29452008000100021

Garcia, F. R. M., Brida, A. L., Martins, L. N., Abeijon, L. M., \& Lutinski, C. J. (2017). Biological Control of Fruit Flies of the Genus Anastrepha (Diptera: Tephritidae): Current Status and Perspectives. In D. Lewis (Org.), Biological Control: Methods, Applications and Challenges (pp. 29-71). Hauppauge: Nova Science Publishers.

Gomes Neto, A. V., Frazão, C. A. V., Silva, J. D. C., França, S. M., Ramos, J. E. R., \& Silva, P. R. R. (2016). Moscas-das-frutas e seus parasitoides em cajazeira no município de Teresina-PI. Revista de Ciências Agrárias, 59(4), 413-416. https://doi.org/10.4322/rca.2233

Holanda, M. J. A. (2012). Diversidade de espécies de Anastrepha Schiner, 1868 (Diptera: Tephritidae) no município de Caxias e no Parque Estadual do Mirador, Maranhão, Brasil (Dissertação Mestrado). Manaus: Instituto Nacional de Pesquisas da Amazônia. 84p. https://bdtd.inpa.gov.br/bitstream/tede/1551/2/Disserta\%C3\%A7\%C3\%A3o_\%20Mery\%20 \%20Jouse\%20de\%20Almeida\%20Holanda.pdf. 03 Aug. 2020

Leite, S. A., Castellani, M. A., Ribeiro, A. E. L., Costa, D. R., Bittencourt, M. A. L., \& Moreira, A. A. (2017). Fruit flies and their parasitoids in the fruit growing region of Livramento de Nossa Senhora, Bahia, with records of unprecedented interactions. Revista Brasileira de Fruticultura, 39(4), 1-10. https://doi.org/10.1590/0100-29452017592

Lemos, L. N., Deus, E. G., Nascimento, D. B., Jesus-Barros, C. R., Costa-Neto, S. V., \& Adaime, R. (2017). Species of Anastrepha (Diptera: Tephritidae), their host plants, and parasitoids in small fruit production areas in the state of Amapá, Brazil. Florida Entomologist, 100(2), 403-410. https://doi.org/10.1653/024.100.0201

Machado, M. C., Carvalho, P. C. L., \& Van Den Berg, C. (2015). Domestication, hybridization, speciation, and the origins of an economically important tree crop of Spondias (Anacardiaceae) from the Brazilian Caatinga dry forest. Neodiversity, 8, 8-49.

https://doi.org/10.13102/neod.81.2 
Marsaro Júnior, A. L., Deus, E. G., Ronchi-Teles, B., Adaime, R., \& Silva Júnior, R. J. (2013). Species of Anastrepha (Diptera: Tephritidae) captured in a guava orchard (Psidium guajava L., Myrtaceae) in Boa Vista, Roraima, Brazil. Brazilian Journal of Biology, 3(4), 879-886. https://doi.org/10.1590/S1519-69842013000400026

Menezes, R. V. S, Nunes, E. M., Branco, R. S. C., \& Zucchi, R. A. (2000). Piauí. In A. Malavasi \& R. A. Zucchi (Org.), Moscas-das-frutas de Importância econômica no Brasil: conhecimento básico e aplicado (pp. 213- 215). Ribeirão Preto: Holos Editora

Moraes, R. C. B., Haddad, M. L., Silveira Neto, S., \& Reyes, A. E. L. (2003). Software para análise faunística. In: $8^{\circ}$ Simpósio de Controle Biológico. 8, p.195.

http://www.lea.esalq.usp.br/softwares. 02 Aug. 2020.

Oliveira, M. B. R., Ferreira, E. N. L., Reigada, C., Lopes, G. N., Lemos, L. J. U., Uramoto, K., ... Zucchi, R. A. (2017). Composition of Anastrepha species (Diptera: Tephritidae) in habitats with different levels of anthropogenic activity. Biotemas, 30(3), 61-69.

https://doi.org/10.5007/2175-7925.2017v30n3p61

Ordano, M., Guillén, L., Rull, J., Lasa, R., \& Aluja, M. (2013). Temporal dynamics of diversity in a tropical fruit fly (Tephritidae) ensemble and their implications on pest management and biodiversity conservation. Biodiversity and Conservation, 22, 1557-1575. https://doi.org/10.1007/s10531-013-0468-6

Piedra, E., Zuñiga, A., \& Aluja, M. (1993). New host plant and parasitoid record in Mexico for Anastrepha alveata Stone (Diptera: Tephritidae). Proceedings of the Entomological Society of Washington, 95(1), 127.

PNDF/MAPA- Plano Nacional de Desenvolvimento da Fruticultura (2020).

https://www.gov.br/agricultura/pt-br/assuntos/noticias/mapa-lanca-plano-de-fruticultura-em-p arceria-com-o-setor-privado/PlanoNacionaldeDesenvolvimentodaFruticulturaMapa.pdf/view 10 Aug. 2020.

Santos, G. S., \& Pádua, L. E. M. (2004). Flutuação populacional e espécies de moscas-das-frutas em citrus na cidade de Teresina, PI. Revista Caatinga, 17(2), 87-92.

Santos, M. S., Navack, K. I., Araujo, E. L., \& Silva, J. G. (2011). Análise faunística e flutuação populacional de moscas-das-frutas (Diptera: Tephritidae) em Belmonte, Bahia. Revista Caatinga, 24(4), 86-93. http://periodicos.ufersa.edu.br/index.php/sistema 23 ago 2019. 05 Aug. 2020.

Sarmento, J. D. A., Morais, P. L. D., Souza, F. I., Costa, L. R., \& Melo, N. J. A. (2015). Bioactive compounds and antioxidant activity of Ximenia americana coming from different collection sites. Alan, 65(4), 263-271.

http://ve.scielo.org/scielo.php?script=sci_arttext\&pid=S0004-06222015000400007\&lng=es\& nrm=iso 27 Aug. 2020.

SAS Statsoft Inc. (2001). Statistical Analysis system for Windows 98. SAS Institute. Version 8.2 , Cary.

Silveira Neto, S., Nakano, O., Bardin, D., \& Vila Nova, N. A. (1976). Manual de ecologia dos insetos. São Paulo: Agronômica Ceres. 


\section{$\triangle 1$ Macrothink}

Sobeh, M., Mahmoud, M. F., Abdelfattah, M. A. O., El-Beshbishy, H. A., El-Shazly, A. M., \& Wink, M. (2017). Hepatoprotective and hypoglycemic effects of a tannin rich extract from Ximenia americana var. caffra root. Phytomedicine, 33, 36-42.

https://doi.org/10.1016/j.phymed.2017.07.003

Sousa, M. M., Martins, D. C., Fernandes, E. C., Ferreira, A. D. C. de L., \& Araujo, E. L. (2017). Moscas-das-frutas (Diptera: Tephritidae) e seus hospedeiros no município de Quixeré, estado do Ceará, Brasil. Revista Verde, 12(3), 530-534.

https://doi.org/10.18378/rvads.v12i3.5371

Subhagan, S. R., Dhalin, D., \& Kumar, A. K. (2020). Dipteran flies in Passiflora L. (Passifloraceae): A comprehensive review. Journal of Entomology and Zoology Studies, 8(4), 2325-2330. http://www.entomoljournal.com. 30 Aug. 2020.

Trassato, L. B., Lima, A. C. S., Bandeira, H. F. S., Monteiro Neto, J. L. L., Silva, E. S., \& Ronchi-Teles, B. (2016). Diversidade e índice de infestação de Anastrepha spp. em goiabeiras comerciais de Boa Vista, Roraima. Revista Brasileira de Ciências Agrárias, 11(4), 317-322. https://doi.org/10.5039/agraria.v11i4a5400

Uchôa M. A. (2012). Fruit flies (Diptera: Tephritoidea): biology, host plants, natural enemies, and the implications to their natural control. In M. L. Larramandy \& S. Soloneski (eds.), Integrated Pest Management and Pest Control: Current and Future Tactics (pp. 271-300). Croatia: In Tech. Available from:

http://www.intechopen.com/books/integrated-pest-management-and-pest-control-current-andfuturetactics/fruit-flies-diptera-tephritoidea-biology-host-plants-natural-enemies-and-the-impl ications-to-their-n.03 Aug. 2020.

Zucchi, R. A. (2000). Taxonomia. In A. Malavasi \& R. A. Zucchi (Org.), Moscas-das-frutas de importância econômica no Brasil: conhecimento básico e aplicado (pp. 13-34). Ribeirão Preto: Holos Editora.

Zucchi, R. A. (2008). Fruit flies in Brazil - Anastrepha species their host plants and parasitoids. www.lea.esalq.usp.br/anastrepha/ 10 Sep. 2020.

Zucchi, R. A., Uramoto, K., \& Souza-Filho, M. F. (2011). Chave ilustrada para espécies de Anastrepha da região Amazônica. In R. A. Silva, W. P. Lemos \& R. A. Zucchi (Eds), Moscas-das-frutas na Amazônia brasileira: diversidade, hospedeiros e inimigos naturais (pp. 71-79). Macapá: Embrapa Amapá.

\section{Copyright Disclaimer}

Copyright for this article is retained by the author (s), with first publication rights granted to the journal.

This is an open-access article distributed under the terms and conditions of the Creative Commons Attribution license (http://creativecommons.org/licenses/by/4.0/). 